\title{
Slang Words Used in Movie Script "Harold and Kumar Go to White Castle"
}

\author{
I Made Yudhi Putrawan*, I Nengah Sudipa, Ni Wayan Sukarini \\ English Department, Faculty of Arts, Udayana University \\ [yudhiputrawan27@gmail.com],[nengahsudipa@yahoo.co.id], \\ [wayansukarini@yahoo.co.id] \\ Denpasar, Bali, Indonesia \\ *Corresponding Author
}

\begin{abstract}
The title of this study is Slang Word Used in Movie Script "Harold And Kumar Go to White Castle". The aims of the study are to identify the types of slang and meaning conveyed in movie script Harold and Kumar Go to White Castle. The data of this study were collected from" Harold and Kumar Go to White Castle" movie script as the data source. The theories used in the study are theory proposed by Allan and Burridge (2006) entitled Forbidden words: Taboo and The Censoring of Language used to identify the types of slang word, and theory proposed by by Leech (1974) entitled Study of Meaning used to analyze the meanings conveyed in the movie. The documentation method is used to collect the data, and descriptive qualitative method is used to analyze the data. There were forty slangs either in the form of words or phrases that are analyzed based on theory mentioned above. There are five types of slang in theory of Allan and Burridge (2006) but only four types were found in the movie script. Those are fresh and creative, imitative, flippant, acronym, and clipping. Flippant type was the most found in the data source. For the meaning, there were seven types of meaning based on the theory proposed by Leech (1974) but only six types were found in the movie script. Those are conceptual meaning, connotative meaning, social meaning, collocative meaning, reflected meaning, and affective meaning. Affective meaning type is the most found in the data source.
\end{abstract}

\section{Keywords: slang words, type of slang, meaning, Harold and Kumar}

\begin{abstract}
Abstrak
Penelitian ini berjudul Kata Slang Digunakan dalam Naskah Film "Harold Dan Kumar Go to White Castle". Tujuan dari penelitian ini adalah untuk mengidentifikasi jenis-jenis slang dan makna yang disampaikan dalam naskah film Harold dan Kumar Go to White Castle. Data penelitian ini diambil dari skrip film "Harold dan Kumar Go to White Castle" sebagai sumber data. Teori yang digunakan dalam penelitian ini adalah teori yang dikemukakan oleh Allan dan Burridge (2006) yang berjudul Forbidden words: Taboo and The Censoring of Language yang digunakan untuk mengidentifikasi jenis-jenis kata slang, dan teori yang dikemukakan oleh Leech (1974) berjudul Study of Meaning digunakan untuk menganalisis jenis-jenis makna kata slang yang disampaikan dalam film. Metode dokumentasi digunakan untuk mengumpulkan data, dan metode deskriptif kualitatif digunakan untuk menganalisis data. Ada empat puluh slangs baik dalam bentuk kata-kata atau frasa yang dianalisis berdasarkan teori yang disebutkan di atas. Ada lima jenis slang dalam teori Allan dan Burridge (2006) tetapi hanya empat jenis yang ditemukan dalam naskah film, yaitu fresh and creative, imitatif,
\end{abstract}


flippant, acronym, dan clipping. Jenis flippant adalah yang paling banyak ditemukan di sumber data. Untuk makna, ada tujuh jenis makna berdasarkan teori Leech (1974) tetapi hanya enam jenis yang ditemukan dalam naskah film, yaitu makna konseptual, makna konotatif, makna sosial, makna kolokatif, makna yang direfleksikan, dan makna afektif. Jenis makna afektif adalah yang paling banyak ditemukan dalam sumber data.

Kata kunci: kata slang, jenis slang, makna, Harold dan Kumar.

\section{INTRODUCTION}

In life, humans use language as a tool to interact with each other and express their personal reaction to the situation. Through language the speakers can identify themselves as well as their language as a symbol of their society. In society people tend to live in certain group of similar social factors and it makes people speak different language and dialect based on their social group. The appearance of many social groups makes variety of languages. One of the varieties of language appears in society is known as slang.

According to Hartman and Stock (1972:165) slang is a variety of speech characterized by newly coined and rapidly changing vocabulary, used by young or social group for communication. Therefore, slang has become common thing in our daily life. According to Chapman (1988) almost everyone uses slang on some occasions, but it is not easy to define the word. Slang has been defined as one of those things that everybody can recognize and nobody can define. Slang is particularly rich in certain areas, such as violence, crime, drugs, and sex. In fact, slang has spread to group of people and entertainment media such as movies .

There are some related studied have been done previously. Those previous study have their own specification related to the subject and object of the study in order to conduct this study, the writer read some previous studies as the example and literature review.

The first article written by Ariyanti
(2018) entitled Slang Word Used by The Characters in Neighbors 2: Sorority Rising. Her study aims to identify the type and to analyze the function of slang words and phrases used by the characters in movie Neighbors 2: Sorority Rising . To collect the data, she utilize documentation and qualitative method.

The second article written by Dewi (2016) entitled American Slang in "Horrible Bosses 2" Movie by Anders and John Morris. This study aims to identify the function of slang and meaning of slang applied by the characters in "Horrible Bosses 2". Her study used descriptive qualitative documentation method.

The third article written by Septirahayuni (2016) entitled Slang Word Used in"21 Jump Street" Movie Script by Michael Bacall. Her study is aims to analyze the slang words expression and slang word formation in 21 Jump Street movie script. The data were collected from"21 Jump Street" movie script using documentation and qualitative method.

The fourth article written by Trimastuti (2017) in her article entitled An Analysis of Slang Words Used in Social Media. In Trimastuti study's is discuss about slang word in case of "alay language" which complicated with Indonesian strandard language due to alay language has many errors in Indonesian language. This study used qualitative method, descriptive techniques to analyze the data and observation method to collect data.

Another article is written by 
Zamaletdinova and Izmaylova (2016) in their article entitled Features of Youth Slang Functioning. It is discusses about the problem of the youth slang in speech. The aims of this study is to learn the lexical semantic features of youth slang and its function in a language environment. In order to identify the reason of slang word usage this study survey among first-year students of Kazan Federal University. The data are collected through questionnaire and interview.

In movies, the slang usage becomes a common thing. This study is focused on slang word used in movie due to people commonly learn slang from their entertainment media especially in movie and through movie they can easy copy the gesture of the slang expression that they watched. The function of slangs in the movies is to bring out social and cultural side of someone's identity such as in 2004 American stoner comedy film, entitled Harold and Kumar Go to White Castle.

Based on the background above, there are two problems as follows: What are the types of slang words used in the movie script "Harold and Kumar Go to White Castle"?, How are the meanings conveyed by slang words in the movie script "Harold and Kumar Go to White Castle"?

Based on the problems above, there are two aims of this study as follows: To identify the types of slang used in movie script "Harold and Kumar Go to White Castle". To analyze the meanings conveyed by slang in the movie script "Harold and Kumar Go to White Castle".

\section{METHOD}

"Methodology is very important and it provides the crucial steps used in conducting scientific research. The research method used in this study is classified into three parts:"

\section{Data Source}

The data of this study were taken from movie script of "Harold and Kumar Go to White Castle". It is a 2004 American stoner comedy film written by John Hurwitz and Hayden Schossberg, and directed by Danny Leiner. This movie is the first instalment of the Harold and Kumar series. It was released on July $30^{\text {th }}, 2004$, by New Line Cinema. This movie was selected as the data in this study because it contained many expressions of slang words in conversation of American as well as there are so many slang terms spoken by the movie's characters which are difficult to understand.

\section{Method and Technique of Collecting Data}

This study is qualitative research where all the data were collected through library research. Documentation technique is used since the data is a movie type. Documentation is method for gathering information by giving record report of certainties of something, particularly by utilizing picture, note taking, and recording. This study used four steps in collecting the data for this research and the steps are:

a. Downloading movie and movie script

b. Watching the movie several times and reading the movie script intensively.

c. Finding the slang words and selecting the slang words in the movie script.

d. Noting all utterances of characters that contain slang words in the movie script.

\section{Method and Technique of Analyzing Data}

"The collected data were analyzed descriptively using qualitative method. The descriptive technique was also applied to describe the writing content clearly." There were some steps to analyze the slang words in "Harold and 
Kumar Go to White Castle" movie script as follows:

a. Identifying the slang words or phrases in each conversation found in the movie script.

b. Classifying the slang words or phrases based on theories.

c. Analyzing the type and meaning conveyed of the slang words in the movie script based on theories.

\section{Method and Technique of Presenting Data}

"According to Sudaryanto (1993:145), there are two types of method that can be used to present the analyzed data," i.e formal and informal methods. Formal method means that the analyzed data were presented using symbol, table, diagram, number. While informal method means presenting the result of the analysis by using words and sentences. This study used informal presentation to present the first and second problem analysis. In regard to explain the categorization from slang word or phrase, the forms of paragraph is used in the data presentation. The paragraph explained some of slang expressions and small portion of explanation about the situation of slang expression dialogue. There were several steps in presenting data analysis, as follow:

a. Presenting the types and meanings conveyed in the slang words.

b. Explaining and elaborating the types and meanings conveyed in the slang words clearly to avoid misunderstanding which is supported with the knowledge based on the theories.

\section{RESULTS AND DISCUSSION}

"There are two main theories used and related to the problems presented in this study. Those are the theory about types of slang words by Allan and Burridge (2006)" called the fresh and creative, imitative, flippant, acronym, and clipping. The theory about meaning proposed by Leech (1974) including conceptual meaning, connotative meaning, social meaning, collocative meaning, affective meaning, reflected meaning, and thematic meaning.

\section{The Slang Types in Harold and Kumar Go to White Castle}

\section{a. Fresh and Creative}

Among all the dialogues in the movie script of "Harold and Kumar Go to White Castle", there are nine slang words that can be considered as fresh and creative type, which "have brand-new vocabulary, clever imagination, informal variety and can be up to date words or even old words that people do not know. Nine slang words found in this research categorized into fresh and creative type are" dude, nah, yeah, yo, scag, yep, bingo, poser, and jew.. "One of the examples is the word dude mentioned in a dialogue, shows that the slang word comes as a new vocabulary and through imagination from the speaker". There are also slang words of yo used in the dialogue referring to someone of informal situation with their informal variety.

\section{b. Flippant}

Among all the dialogues in the movie script of "Harold and Kumar Go to White Castle", there are twenty-six slang words that can be considered as flippant type. In this study, the point "of grouping slang word into flippant is when the slang form consists of more than two words and do not have any relationship to the denotative meaning". The slang words found in this research are love stains, crunching numbers, finest herb, boney ass, fat blunt, yellow plague, yellow 
fever, Asian chick, sweet lord, getting high, cock boy, twilight zone, holy shit, pipe down, kiss of death, give a fuck, what the hell, get the hell, fucking cute, what the fuck, where the hell, how the hell, fucking hot, fucking asshole, blitzed out, and chill out. "One of the examples is the phrase blitzed out which consists of two words that are blitzed and out. Each of the two words has different meaning but when the two words are put together into one phrase the meaning is different from the original words".

\section{c. Imitative}

Among all the dialogues in the movie script "Harold and Kumar Go to White Castle", there are twenty slang words that can be considered as "imitative type, in which the slang word form imitates the other words or combination of two words that result in different meaning. The slang words found in this study that are considered as imitative type are" sucks, chick, damn, asshole, shitload, bullshit, fuck, blazed, sucked, shit, high, pussy, chronic, poetry, dicks, horny, bitch, hippie, twinkie, and lord. One of the examples is shit, "which is a kind of slang word that fully imitates the original word but has different meaning than the original word. The original meaning of the word shit is feces but it changes into a word that refers to phrase to abuse someone or expression of bad situation". The other example is bullshit, which originated from two words bull and shit, combined into one and create a new meaning.

\section{d. Clipping}

Among all the dialogues in the movie script "Harold and Kumar Go to White Castle", there are five slang words that can be considered as clipping type, where this slang word is identified by deleted word "in one or some parts but still has the same meaning as the uncut one. The deletion of some part of the word in slang expression is one of the usage forms of imagination and effort to reach certain point in communication". "The imagination of slang expression and effort only apply in certain group or place". Several slang words found in this research that are grouped as clipping type are bro, cops, gonna, gotta and nope. "One of the examples is the word bro, which is a slang word where the original word" is brother and its meaning still has the same meaning with the original word.

\section{The Types of Meaning in Harold and Kumar Go to White Castle}

a. Conceptual Meaning

Conceptual meaning is identified where words acquired its own meaning unlike the other meaning which consist of peripheral meaning. There are eight slang expressions found in this study that are categorized into conceptual meaning: gonna, gotta, what the hell, get the hell, bingo, what the fuck, where the hell, , and fucking poser. Those slang expressions can differ based on what it represents such as situation, attitude, and person. There is also conceptual meaning type that explicitly contains affective meaning type to express speaker expression.

Data: Gonna

The dialogue happened through telephone while Harold in his Office and Kumar in med school interview. It is uttered by Harold in the conversation with Kumar. The usage of slang word gotta appeared in the part of scene when Harold called Kumar and in voice that he cannot smoke together as usual. The scene is started when Harold taking on his office phone to call Kumar, Harold utterance "I'm not gonna able to partake in our usual Friday night ritual. I've gotta stay late at the office". The slang word gotta is categorized into conceptual 
meaning slang as it has its denotative meaning without any associative meaning. The word gotta has literal meaning "have got to".

\section{b. Connotative meaning}

Connotative meaning is a kind of slang expression that has expressed meaning of the communicative value above the core meaning of the word. Each of the slang expression has meaning that holds the properties of a word from point of view, which already clings to each individual, group, and the society. Connotative meaning varies considerably according to the culture, historical period, and the experience of the individual. There are eight slangs found in this study that are categorized into connotative meaning: yellow plague, jews, yellow fever, getting high, finest herb, Asian chick, hippie, love stains, and twinkie. The connotative meaning can be differentiated based on what it represents, such as attitude, person, thing, condition, and situation.

Data: Yellow Plague

The slang phrase Yellow plague is categorized to connotative meaning that represented person. The slang expression occurred in the dialogue between Kumar and Goldstein, when Harold and Kumar stopped in the road due to Harold bitted by racoon and Goldstein tried to help them. The scene is started after Kumar noticed Harold and Goldstein having fun at the Asian student party in Pricetown tonight. Goldstein replied it, he uttered "Man, I have the yellow plague. There's nothing sexier that a hot Asian chick...or dude for that matter". The slang expression yellow plague in the dialogue represented person that refers to a group of Asian people which live in America. It is categorized into connotative meaning type due to the word yellow holds a communicative value in the Western society, which the word yellow is used to determine Asian, Chinese, Japanese people based on the color of skin. The slang phrase yellow plague in the dialogue is also used to emphasize Asian person based on the word yellow that refers to the group of Asian students.

\section{c. Social meaning}

Social meaning refers to the meaning conveyed by the pierce of language about the social context. "It is related to the situation in which an utterance is used" as well as concerned with social circumstances. The usage of social meaning refers the social context of slang word itself to deliver the meaning of the slang word. The social meaning will be varying due to each person has different level and variation in social knowledge. Beside that dialect is also the factor of recognizing some words. The point of view to define social meaning is the relation between social meaning and the usage of situation in the utterance. Several slang expressions found in this study that categorized into social meaning types, such as dude, bro, yo, getting high, chill out, blitzed out, yeah, bingo, scag, yep, bitch, give a shit, and nah. The both of slang expressions intended to show friendliness and intimate relation. In addition, there also several social meaning of slang expressions that conveyed the affective meaning which represented the expression of the speaker.

Data: $Y o$

The slang word yo is one of slang words where the word is used to make the situation less formal. The slang occurs in the part of dialogue, when Harold paranoid of rabies after he was bitten by racoon. It is uttered by Goldstein in the conversation between he, Kumar and Harold about rabies infection. In the Goldstein utterance " $Y o$, we gotta hit the Asian party." The use of slang word yo in the dialogue is to reduce the situation of Kumar and Harold debate 
and to make the situation less formal. Beside that the word yo is also used to show friendliness in the speaker target. The slang word yo is categorized into social meaning because it is used in the context of situation in the speaker utterance.

\section{d. Affective Meaning}

"The usage of slang expressions that based itself on the expression of emotion that is expressed from the speaker or the writer is something that usually happens in daily conversation". The expression happened in order to deliver the speaker feeling to the listener or reader. In term of meaning of slang the expressions or attitudes are often inserted in affective meaning. Affective meaning is meaning that describes what is communicated of the feeling and attitudes of the speaker. Affective meaning has more directly a reflection of the speaker's personal attitude or feeling toward the listener of the target of the utterance. Feelings or attitudes in affective meaning slang are usually negative. "Several slang expressions found in this study categorized as affective meaning" type are holy shit, asshole, bullshit, shit, what the hell, get the hell, what the fuck, fuck, where the hell, sucked, how the hell, godammit, sweet lord, give a fuck, fucking asshole, prick, dumbass, fucking hot, and fucking cute. In this study several emotions occur from the usage of the affective meaning such as surprised, anger, awe, hate, and passionate. Mostly, the affective meaning type "occurred explicitly together with another type in one slang expression".

Data: Holy shit

The usage of slang expression holy shit in the movie occurred in the Harold utterance. The dialogue is between Harold and Kumar. The scene happened while Harold and Kumar stopped at traffic jam beside the movie theater. After the crowd entered the movie theater
Kumar saw Maria and he uttered "Hey, check it out! Your movie playing... and look who to see it". Harold seems surprised after he knows there is Maria and he uttered "Holy shit". The usage of slang expression holy shit in the Harold utterance is categorized as affective meaning type which expressed Kumar emotion of surprised to see his dream girl. It also expressed that Harold bashful to greet Maria due to he is always panic and nervous with her. Meanwhile, the major meaning of phrase holy shit is affective type. It also has collocative meaning because of the phrase company meaning is from a certain word which created different meaning.

\section{e. Collocative Meaning}

Collocative meaning is the meaning that occurred because of acquiring company meaning from a certain word. The words will produce different meanings when collocate with different words. Mostly the collocative meaning conveys the adjective followed by noun. The slang expression categorized as collocative meaning type can be differentiated based on what the slang expression represents such as action or situation. There are also some slang expressions that explicitly conveyed affective meaning which expressed emotion from the speaker such as hate and anger. The slang word that is categorized as collocative meaning type found in this study is kiss of death, bullshit, asshole, boney ass, fat blunt, take a bow, work horse, dumbass and shitload.

Data: Kiss of death

One of collocative meaning type in this study is slang phrase kiss of death. The slang phrase kiss of death is used in Kumar utterance. It occurred in the scene of Harold going to meet Maria in her room but she already left to Amsterdam for ten days. Know that thing, Kumar 
uttered to Harold "For a hot chick, ten days in Europe is the kiss of death. There are gonna be suave, sophisticated guys all over her, by the time she gets back, she not be available". The slang phrase kiss of death is consisting of word kiss and death. The word kiss means touch with lips as a sign of love, while the word death means the end of life of a creature. However, when the word kiss and death are collocated it becomes new meaning. The slang phrase kiss of death in Kumar utterance refers to feeling of missing someone so much.

\section{f. Reflected Meaning}

Reflected meaning is the type of meaning that arises in case of multiple conceptual meaning, when one sense of a word is conveyed and response to another sense. "Several slang expressions found in this study that are categorized into reflected meaning type are shit", high, horny, lord, chronic, pussy, poetry, chick, and dick. Some of reflected meaning found in this study also expressed affective meaning explicitly which conveyed feeling from the speaker.

Data: Chick

The word chick is categorized to slang word that has meaning reflected on its word. The word chick in the film is appeared in the scene of Harold and Kumar, especially in the apartment when Harold know that Maria has already moved to Europe. It is uttered by Kumar when he persuaded Harold. In Kumar utterance "For a hot chick, ten days in Europe is the kiss of death. There are gonna be suave, sophisticated guys all over her, by the time she gets back, she not be available". In this case the word chick means woman. The word chick is categorized into reflected meaning due to there is another meaning sense of word chick, such as the word chick which means kind of bird who cannot fly.

\section{CONCLUSION}

"Based on the previous discussion of analyzing slang word of Harold and Kumar Go to White Castle movie script, conclusion can be drawn as as follow:

The types of slang were analyzed based on theory proposed by Allan and Burridge (2006)". There are five types of slang based on the theory but only four types "found in this study namely; fresh and creative, imitative, flippant, and clipping. Generally, the most slang type used in this movie script is flippant". It is because most of the slang used in the movie script is formed from two or more words and achieves their own meaning, which different from the source word. A part from type of slang, this study also discusses about the type of meaning using theory proposed by Leech (1974). Based on the theory there are seven types of meaning but only six types are found in the movie script of Harold and Kumar Go to White Castle movie they are; conceptual meaning, connotative meaning, social meaning, collocative meaning, reflected meaning, and affective meaning. However, thematic meaning is not found in the movie script since there are no slang which the message are organized in terms of passive or active sentence used in the movie script did not concern the occurrence of slang expression. The most types of slang meaning found in the movie script is affective meaning type, where the slang word is expressing the speaker emotion.

\section{REFERENCES}

Allan, Keith and Burride, Kate. (2006). Forbiden words: Taboo and The Censoring of Language. Cambridge University Press.

Ariyanti, Made Dessy. (2018). Humanis . Slang Word Used by The Characters in Neighbors 2: 
Sorority Rising. Vol XXII, No 4, 2018.

Chapman, Robert L. (1998). A New Dictionary of American Slang. London: Harper \& Row Publishers Inc.

Coupland, N. (1992). Style: Language variation and identity. Key Topics in Linguistics. Volume XXXIV, No. 1, Winter, pp 209.

Dewi, Luh Putu A.S. (2016). Humanis. American Slang in "Horribe Bosses 2" Movie by Anders and John Morris. Vol XVII, No 3, 2016.

Jamal, R.F and Nasrum. (2018). Elite: English and Literature Journal. Language Style Used in J.K. Rowling's Harry Potter and The Cursed Child. Volume 5, No, 2, pp $190-200$

Jawas, N.M. (2015). Humanis. Language Style Used by Fangirls in Japanese Idol Online Community. Volume 16. No. 1. Juli 2016

Hartman, R.R.K., and Stock, F.C. (1972). Dictionary of Language and Linguistics. London

Leech, Geoffrey. (1974). Semantic: The Study of Meaning. Harmondsworth: Penguin.

Prinz, Jesse J. (2007). When film is art. Available from: http://www.subcortex.com [Accessed on 24 September 2018]

Rashid, S. K. M., \& Zainal, H. (2013). A contrastive study of language style altawkid between malay and arabic languages. Volume XXXV, No. 2, December, pp 19-25.
Rudolf, Arnheim. (1957). Film is an art. University of California Press Berkeley and Los Angeles. California

Septirahayuni, Putu Devi. (2016). Humanis. The Slang Word Used in "21 Jump Street" Movie Script by Michael Bacall. Volume XVI. No. 3. September 2016

Simamora, M. (2016). The Episteme Journal of Linguistics and Literature. Language Style Found in Indonesian Movies. Volume 3, No. 1, August.

Spolsky,B. (1998). Sociolinguistics. London: Oxford University Press.

Tololiu, Y.G. (2017). Humanis. Language Styles with Reference to The Movie Ella Enchanted by Gail Carson Levine. Volume 19, No.1, March.

Trimastuti, Wahyu. (2017). Jurnal Dimensi Pendidikan and Pembelajaran. An Analysis of Slang Word Used in Social Media. Volume V, No.1, July 2017

Yule,G. (1986). The Study of Language. Cambridge: Cambridge University Press

Zamaletdinova, Gulyusa and Zamaylova, Guzel. (2016). Features of Youth Slang Functioning. Kazan: Kazan Federal University. 